\title{
11. PLANKTONIC FORAMINIFERS FROM OLIGOCENE TO PLEISTOCENE SEDIMENTS, DEEP SEA DRILLING PROJECT LEG 921
}

\author{
Karen Romine, The University of Rhode Island, Kingston ${ }^{2}$
}

\begin{abstract}
Leg 92 of the Deep Sea Drilling Project cored sediments containing calcareous microfossils at six sites along $19^{\circ} \mathrm{S}$ latitude in the South Pacific Ocean. Shipboard examination of these sediments revealed planktonic foraminifers of uppermost Oligocene through Pleistocene age that were identified and assigned to biostratigraphic zones according to the tropical zonation scheme of Blow (1969).

Preservation of planktonic foraminifers in the sites from Leg 92 has been affected by the position of each site with respect to the lysocline and calcium carbonate compensation depth (CCD) at the time of deposition, depth of burial, and sediment accumulation rate (rate of burial). An additional factor may also be important, especially in the sediments deposited immediately above basement. Evidence of poor preservation in basal sediments of Holes $600 \mathrm{C}$ and 601 , which have always been shallower than both the lysocline and the $\mathrm{CCD}$, suggests that hydrothermal solutions circulating within young oceanic crust may penetrate the overlying sediments and affect the preservation of calcareous microfossils deposited there.
\end{abstract}

\section{INTRODUCTION}

Leg 92 of the Deep Sea Drilling Project left Tahiti on February 23, 1983 and arrived in Panama on April 19, 1983. Nineteen holes were drilled at six sites along a traverse at $19^{\circ} \mathrm{S}$ latitude in order to study evidence of ancient hydrothermal activity that occurred when the crust was newly formed and young (Table 1; Fig. 1). Sediments containing calcareous microfossils were recovered from all six sites. This report presents the results of shipboard examination and preliminary zonation of samples containing planktonic foraminifers.

The data tables in this report are not complete representations of the assemblages in each sample. They are meant to demonstrate the approximate (and subjectively determined) relative abundances of those species used to make the zonal assignments as well as the state of preservation of the samples. Core-catcher samples as well as a few samples from within selected cores were examined for this purpose.

The six sites of Leg 92 presently lie within the northernmost part of the subtropical water mass of the Southern Hemisphere. The spreading history of the crust at all sites suggests they have always been tropical-warm subtropical, and therefore the tropical zonation scheme of Blow (1969) has been utilized in this study. Modifications to this zonation scheme as proposed by Srinivasan and Kennett (1981) have been incorporated, particularly concerning the definition of the Oligocene/Miocene boundary by the first appearance of Globoquadrina dehiscens, which splits Blow's Zone N4 into two parts: uppermost Oligocene Zone N4A (base defined by first appearance of Globigerinoides species) and lowermost Miocene Zone N4B (base defined by the first appearance of Globoquadrina dehiscens).

\footnotetext{
${ }^{1}$ Leinen, M., Rea, D. K., et al., Init. Repts. DSDP, 92: Washington (U.S. Govt. Printing Office).

2Present address: Exxon Production Research Co., P.O. Box 2189, Houston, TX 77001.
}

Table 1. Locations and water depths of Leg 92 holes.

\begin{tabular}{lccc}
\hline Hole & $\begin{array}{c}\text { Latitude } \\
(\mathrm{S})\end{array}$ & $\begin{array}{c}\text { Longitude } \\
(\mathrm{W})\end{array}$ & $\begin{array}{c}\text { Water depth } \\
\text { (corrected m) }\end{array}$ \\
\hline 597 & $18^{\circ} 48.38^{\prime}$ & $129^{\circ} 46.23^{\prime}$ & 4167 \\
$597 \mathrm{~A}$ & $18^{\circ} 48.43^{\prime}$ & $129^{\circ} 46.22^{\prime}$ & 4163 \\
598 & $19^{\circ} 00.28^{\prime}$ & $124^{\circ} 40.61^{\prime}$ & 3699 \\
599 & $19^{\circ} 27.09^{\prime}$ & $119^{\circ} 52.88^{\prime}$ & 3654 \\
$600 \mathrm{C}$ & $18^{\circ} 55.70^{\prime}$ & $116^{\circ} 50.45^{\prime}$ & 3398 \\
601 & $18^{\circ} 55.22^{\prime}$ & $116^{\circ} 52.11^{\prime}$ & 3433 \\
602 & $18^{\circ} 54.41^{\prime}$ & $116^{\circ} 54.68^{\prime}$ & 3535 \\
\hline
\end{tabular}

\section{SHIPBOARD OBSERVATION}

Site 597

Site 597 is the westernmost site of the transect along $19^{\circ} \mathrm{S}$. The basement age at this site is calculated to be approximately $28.6 \mathrm{Ma}$ (Rea, this volume). Two holes were hydraulically piston cored at this site, and both contain a record of lower Miocene to uppermost Oligocene planktonic foraminifers (Table 2).

Hole 597 was cored to basement at $54.7 \mathrm{~m}$ sub-bottom depth. Abundances of planktonic foraminifers vary, but the older samples are impoverished. Preservation is generally poor. In most samples there are many fragments and few specimens from the size fraction coarser than $150 \mu \mathrm{m}$. The upper three cores from this hole appear to be early Miocene in age (Table 2; Fig. 2). However, the lack of Orbulina species in Section 597-1,CC may be due to the poor preservation of the sample (which is also indicated by the dominance of thickly calcified Sphaeroidinellopsis species), so it is possible that the sample may be earliest middle Miocene in age. A middle Miocene age would be in accord with the nannofossil age determination (Knüttel, this volume).

The assemblage found in the first core-catcher sample of Hole $597 \mathrm{~A}$ is a poorly preserved and impoverished association of middle and early Miocene foraminifers and could not be assigned to a zone. Cores 597A-2 


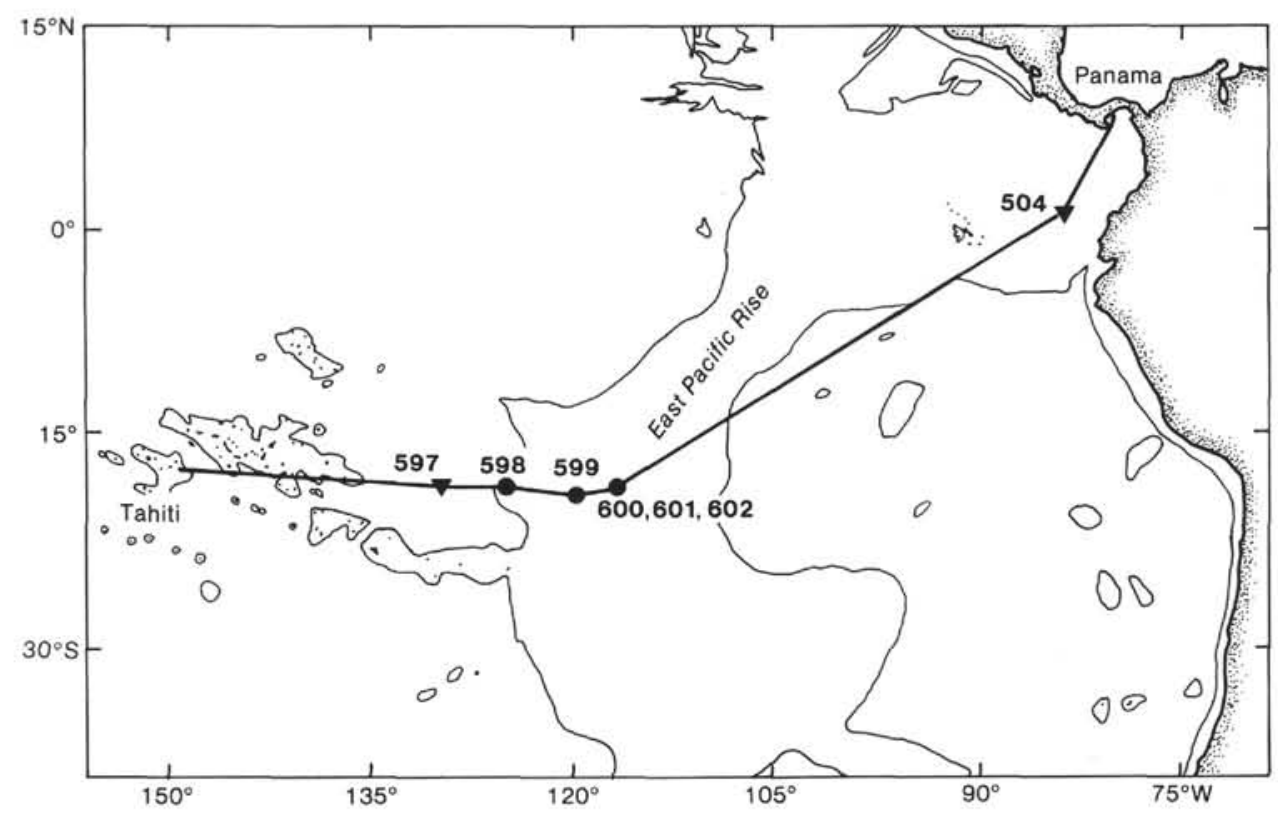

Figure 1. Location of Leg 92 sites on Tahiti-to-Panama transect of the East Pacific Rise. Inverted triangle denotes re-entry.

Table 2. Site 597 planktonic foraminifer species distribution, abundance, and preservation.

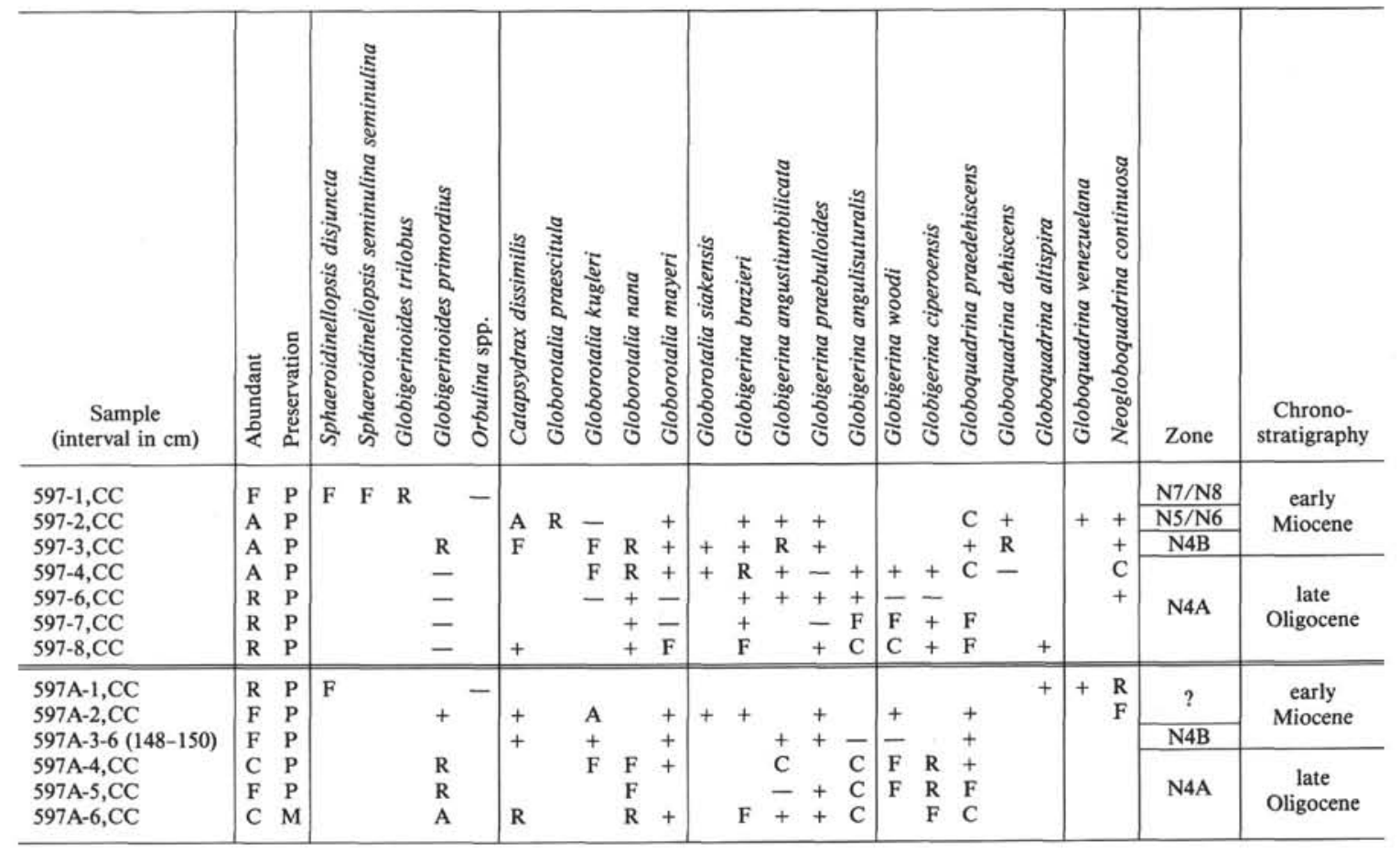

Note: $\mathrm{A}=$ abundant $\mathrm{C}=$ common; $\mathrm{F}=$ few; $\mathrm{R}=$ rare; $+=$ present, but not subjectively quantified; $-=$ absent, but looked for; blank $=$ absent. $\mathrm{G}=$ good; $\mathrm{M}=$ moderate; $\mathrm{P}=$ poor.

and -3 contain abundant Globorotalia kugleri with no strictly Oligocene marker species (e.g., no specimens of Globigerina angulisuturalis), so has been assigned to Zone N4B (Table 2). Cores 597A-4, -5 , and -6 contain both $G$. angulisuturalis and $G$. ciperoensis and have been assigned to Zone N4A. Although the Oligocene/Miocene boundary marker Globoquadrina dehiscens was not found in the earliest Miocene samples because of poor preserva- tion, this boundary can be placed in Core 597A-4 above the last occurrence of Globigerina angulisuturalis. This placement agrees with the nannofossil determination (Knüttel, this volume).

\section{Site $\mathbf{5 9 8}$}

At Hole 598 (Table 3), $44.8 \mathrm{~m}$ of sediment, spanning the uppermost lower Miocene to Pleistocene, were re- 

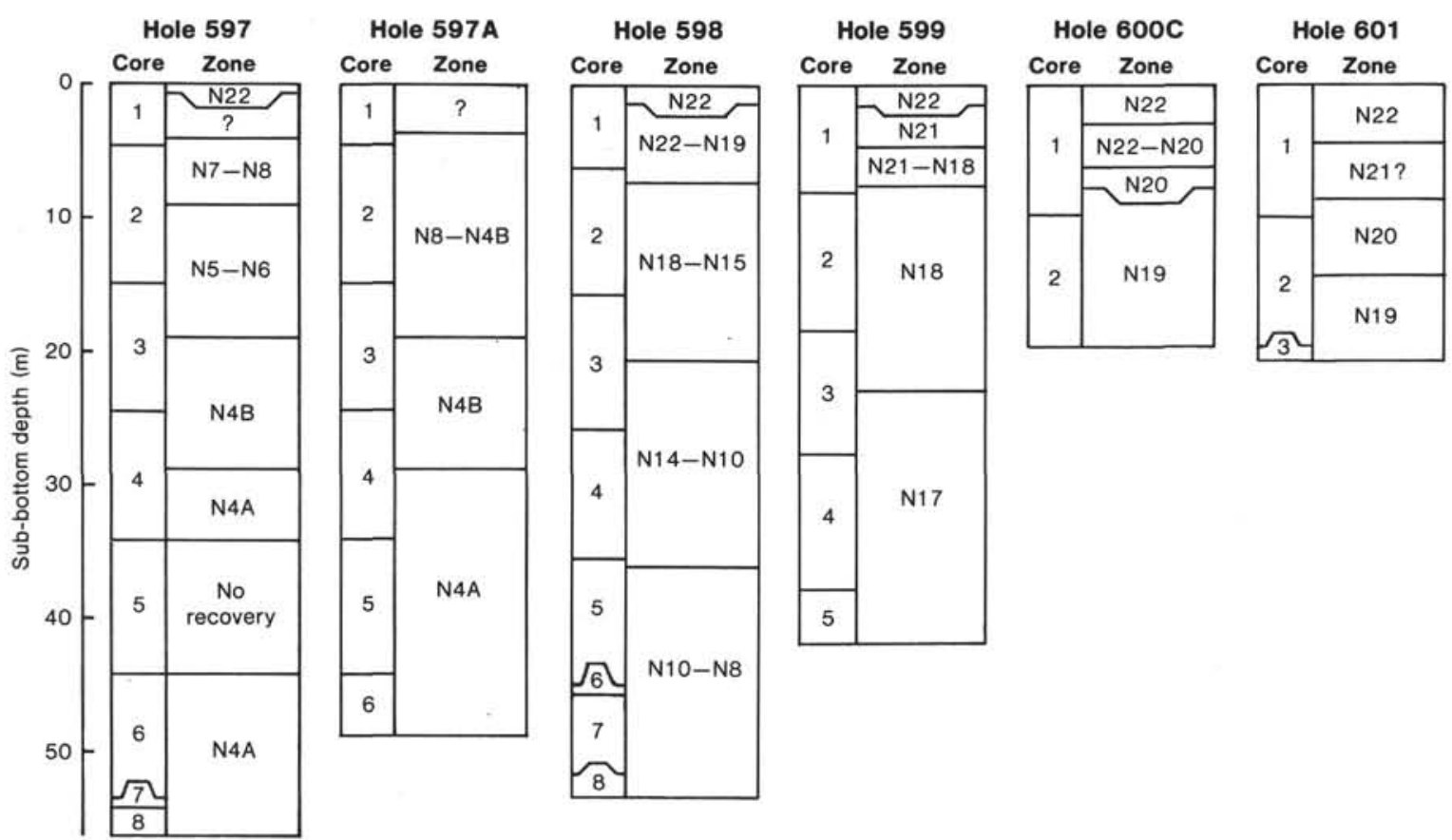

Figure 2. Foraminiferal stratigraphy of Leg 92 sites. Zones after Blow (1969).

covered from the first six cores. An additional $40 \mathrm{~cm}$ of nannofossil chalk and limestone recovered below the sediment unit are late early Miocene in age (nannofossil determination). Basement age below this site is approximately $16.0 \mathrm{Ma}$.

Planktonic foraminifers were rather more abundant than at Site 597 in nearly all samples examined. Preservation was poor to moderate in Hole 598. Some reworked specimens were found in Cores 598-1, -2 , and $\mathbf{- 3}$, but a more detailed examination of more closely spaced samples is needed to determine the extent of reworking. Lithologic examination of Cores 598-4 and -5 revealed the presence of thin turbidite layers rich in foraminifers. These layers have not yet been examined but would be worthy of more detailed study to determine origin and age.

The Pleistocene/Pliocene boundary lies in Core 598-1 (Table 3; Fig. 2). Pleistocene Zone N22 is indicated by the presence of both Globorotalia truncatulinoides and Globigerinoides fistulosus in Sample 598-1-1 (140-150 $\mathrm{cm})$. The assemblage from Section 598-1,CC indicates an early Pliocene age, Zone N19. The Pliocene/Miocene boundary appears to lie in the uppermost part of Core 2. Sample 598-2-2 (140-150 cm) has been assigned to Zones N17/N18; the presence of Sphaeroidinellopsis paenedehiscens suggests an age no older than N17B, and the presence of possible fragments of Globorotalia tumida tumida suggest an age no older than N18. Sections $598-2, C C,-3, C C$, and $-4, C C$ are middle Miocene in age. Some reworked specimens are noted. The absence of Orbulina species in Sections 598-5,CC and -6,CC indicates an early Miocene age. A zonal assignment to N8 has been made on the basis of the presence of both Globigerina brazieri and Globigerinoides sicanus within the same samples. However, specimens of $G$. parawoodi and Globigerina connecta may actually suggest a slightly older zonal designation (N7).
Site 599

Three holes were drilled at Site 599; two of these recovered sediments (Table 4). Hole 599 recovered a continuous section of late Miocene to Pleistocene sediments. Planktonic foraminifers were abundant and better preserved at this site than at either Site 597 or 598 . Reworked late Miocene foraminifers were found in Sample 599-1-3 (140-150 cm), which is late Pliocene in age. Considerable reworking in the upper $20-30 \mathrm{~m}$ of this hole was also indicated by nannofossil distributions (Knüttel, this volume). There is large-scale lithologic "banding" of alternating color zones, which have sharp lower contacts and grade upward; these characteristics suggest turbidite deposition as well.

The uppermost sample examined in Hole 599 contained a Pleistocene assemblage with Globorotalia truncatulinoides, G. tosaensis, and Neogloboquadrina dutertrei (Table 4). The Pleistocene/Pliocene boundary is well constrained to a position within the first $1.5 \mathrm{~m}$ of the first core, since the remaining samples examined in Core 1 above the core-catcher are late Pliocene (Zone N21) in age (Table 4 and Fig. 2). Samples from corecatchers of both Cores 599-1 and -2 have been assigned to late Miocene Zone N18 because they contain Globorotalia tumida tumida, which marks the base of N18, and $G$. merotumida, whose range extends no younger than N18. G. tumida tumida was sought but not found in the remaining core-catchers $(599-3, \mathrm{CC},-4, \mathrm{CC}$, and $-5, \mathrm{CC})$. The presence of Sphaeroidinellopsis paenedehiscens $(599-3$, CC), Pulleniatina primalis $(599-4, C C)$ and Globorotalia plesiotumida $(599-5, C C)$ in the absence of G. tumida places these samples within Zone N17. This suggests that the age at the bottom of the hole is between 7.0 and $8.0 \mathrm{Ma}$, in agreement with basement age of about 8.0 Ma estimated from magnetic anomalies. 


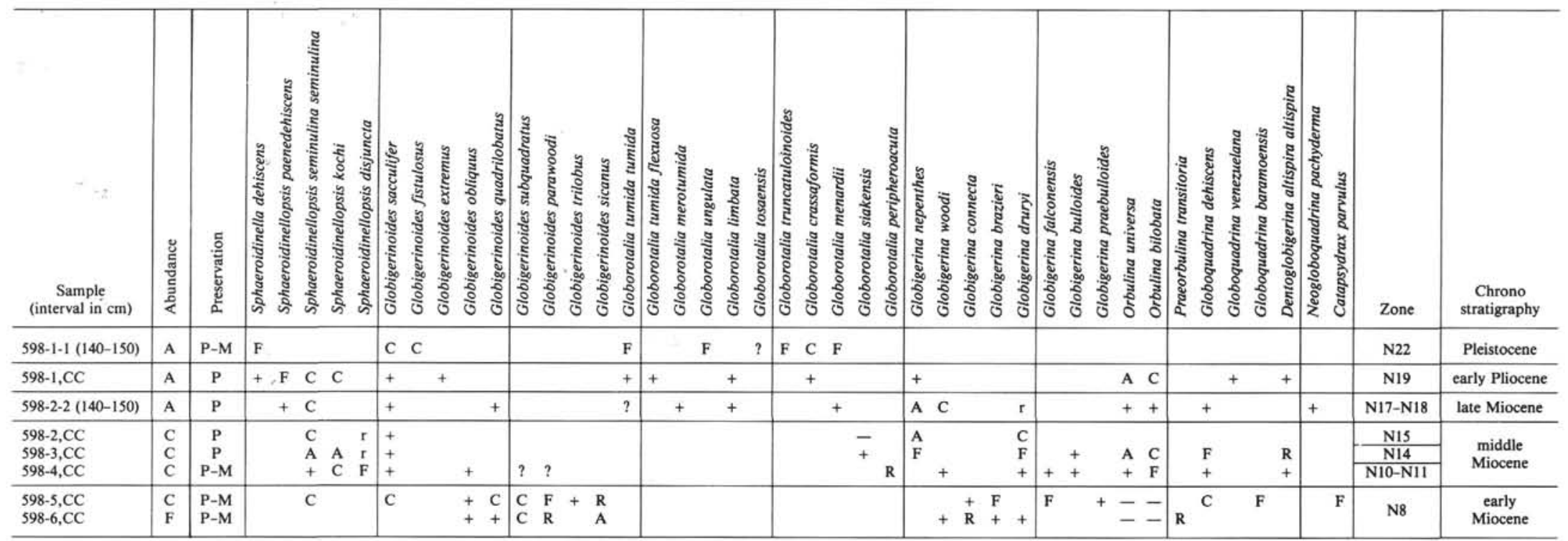

Note: See Table 2 for key. ? = tentative identification; $r=$ reworked.

Table 4. Site 599 planktonic foraminifer species distribution, abundance, and preservation.

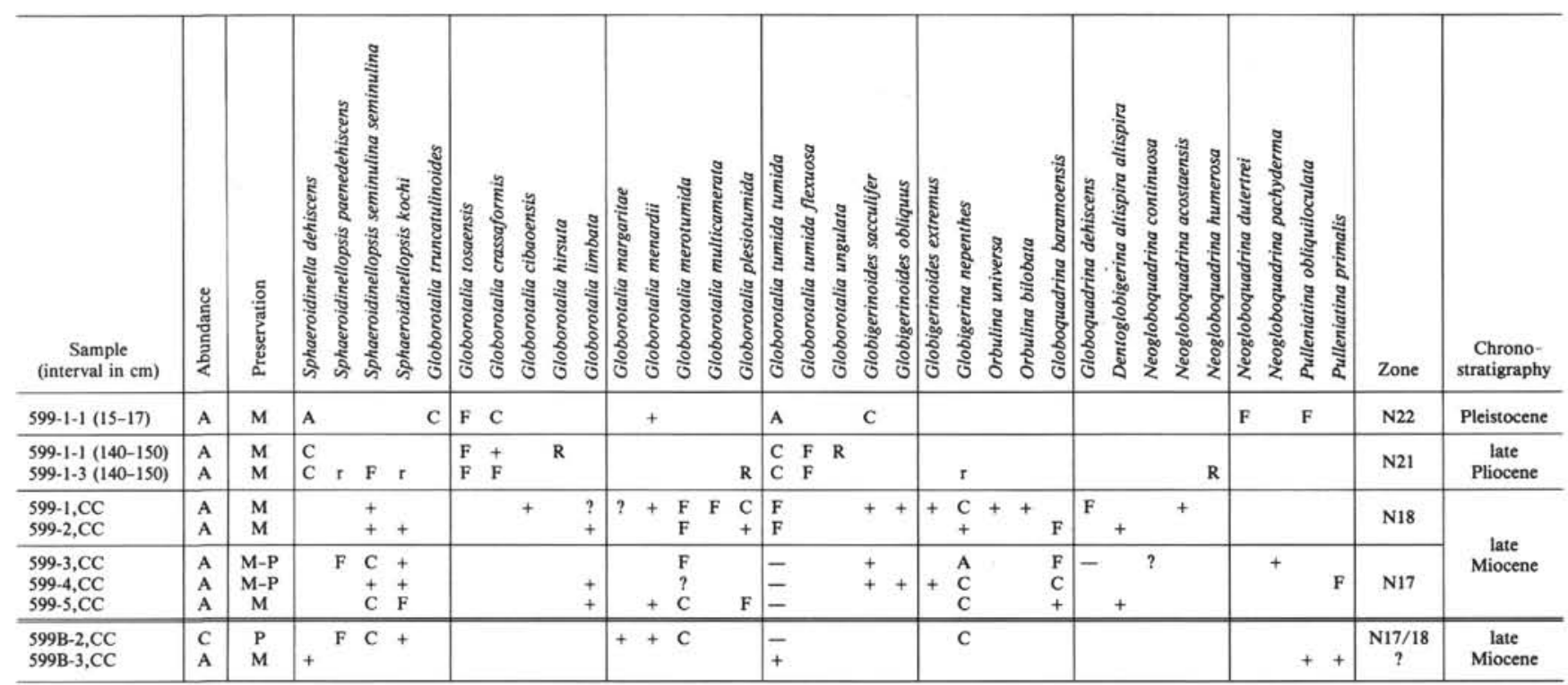

Note: See Table 3 for key. 
A second hole, Hole 599B, was washed to $23.6 \mathrm{~m}$ above basement and then cored so as to recover the sediment/basement interface. Two cores were recovered; Core 599B-2 sampled sediment and Core 599B-3 recovered basement gravel mixed with sediment. Section 599B-2,CC contained late Miocene fossils, but no distinction between Zones N17 and N18 could be made. The gravel sample contained a mixed assemblage of Pleistocene through late Miocene microfossils, probably as the result of the coring process.

\section{Site 600}

Site 600 (Table 5), the fourth site on the east-west hydrogeology transect, was to be the high-heat-flow endmember of a set of three sites drilled on East Pacific Rise crust aged approximately 4.6 Ma. Four holes were attempted at Site 600 because of thin sediment cover and locally variable heat flow. Three of these recovered sediment and were examined for biostratigraphic information.

Planktonic foraminifers were abundant in most samples, and preservation was moderate to good in the younger samples (Table 5). Two samples examined from Hole 600 , a "surface" sample and the first core-catcher, contained a Pleistocene assemblage that included Globorotalia truncatulinoides. Globigerinoides fistulosus, and Beella digitata. Hole 600B had only one core, and its core-catcher age was also Pleistocene (Table 5). Reworked Pliocene material was evident in all samples from these holes.

In Hole $600 \mathrm{C}$, sediments were successfully recovered down to basement. The distribution of nannofossils (Knüttel, this volume) indicates that the Pleistocene/Pliocene boundary is within Core $600 \mathrm{C}-1$, probably in Section 3 ( 3.0 to $4.5 \mathrm{~m}$ sub-bottom depth). Sections $600 \mathrm{C}-1-1$ and -2 contain Pleistocene fossils, with some reworked Pliocene specimens like the samples examined in Holes 600 and 600B. Sample $600 \mathrm{C}-1-4(145-150 \mathrm{~cm})$ contains early Pliocene fossils but no evidence of Globigerina nepenthes; thus, it has been assigned to Zone N20. G. nepenthes is found in all the remaining samples in company with Globorotalia tumida, G. tumida flexuosa, $G$. margaritae, and Sphaeroidinellopsis seminulina kochi. The presence of G. margaritae in Sections 600C-1,CC and $600 \mathrm{C}-2, \mathrm{CC}$ and the presence of Pulleniatina praecursor in Section 600C-1,CC constrains these samples to Zone N19.

\section{Site 601}

Site 601 was planned as the intermediate-heat-flow site of the three drilled on 4.6-Ma crust. Three holes were cored, one for heat-flow measurements and two for sediment recovery. Hole 601 recovered approximately $20 \mathrm{~m}$ of early Pliocene to Pleistocene sediments. At Hole $601 \mathrm{~B}$, the lower part of the sediment section and the sediment/basalt contact was cored. An early Pliocene age was determined from the biostratigraphy, which agrees well with the estimated crustal age of $4.6 \mathrm{Ma}$.

Preservation and abundance of foraminifers in Hole 601 are similar to those of Hole $600 \mathrm{C}$ (Tables 5 and 6), the foraminifers being best preserved and most abundant in younger sediments and less well preserved and fewer in the oldest material. The stratigraphy is similar to that of Hole $600 \mathrm{C}$, and reworked early Pliocene fossils are found in most of the younger samples. Most of Core 601-1 contains a Pleistocene assemblage dominated by Globorotalia truncatulinoides, G. tosaensis, and Globigerinoides fistulosus. However, because of the greater abundances of Pliocene species in Sections 601-1-4 and 601-1-5, the Pleistocene/Pliocene boundary has been

Table 5. Site 600 planktonic foraminifer species distribution, abundance, and preservation.

\begin{tabular}{|c|c|c|c|c|c|c|c|c|c|c|c|c|c|c|c|c|c|c|c|c|c|c|}
\hline $\begin{array}{c}\text { Sample } \\
\text { (interval in } \mathrm{cm} \text { ) }\end{array}$ & 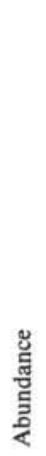 & 涪 & & 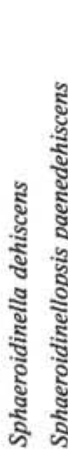 & 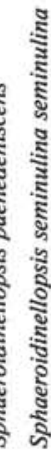 & 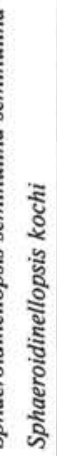 & 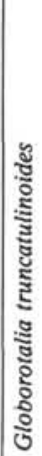 & 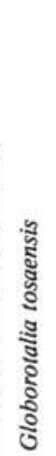 & 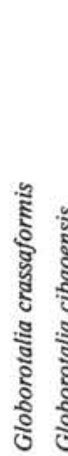 & 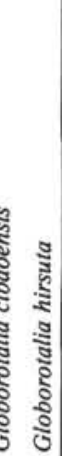 & 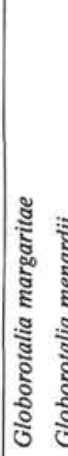 & 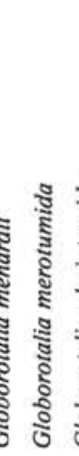 & 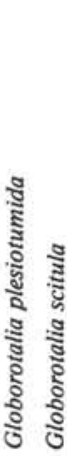 & 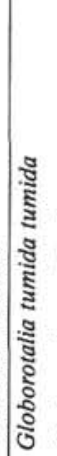 & 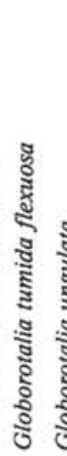 & 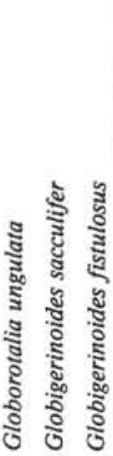 & 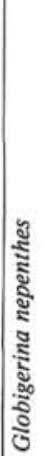 & 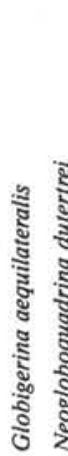 & 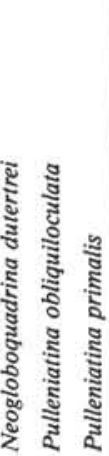 & 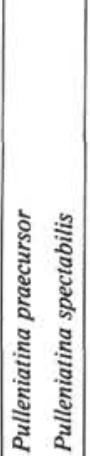 & Zone & $\begin{array}{c}\text { Chrono- } \\
\text { stratigraphy }\end{array}$ \\
\hline $\begin{array}{l}600 \text { top } \\
600-1, \mathrm{CC}\end{array}$ & $\begin{array}{l}\mathrm{A} \\
\mathrm{A}\end{array}$ & $\begin{array}{c}\mathrm{G}-\mathrm{M} \\
\mathrm{M}\end{array}$ & & $\begin{array}{l}\mathrm{C} \\
+\end{array}$ & & $\mathrm{r}$ & $\begin{array}{l}\mathrm{F} \\
\mathrm{R}\end{array}$ & $\begin{array}{l}\mathrm{R} \\
\mathrm{R}\end{array}$ & $\begin{array}{l}+r \\
+r\end{array}$ & & & $+?$ & + & $\begin{array}{l}\text { C } \\
+\end{array}$ & $\begin{array}{l}\mathrm{r} \\
\mathrm{r}\end{array}$ & $?{ }^{\mathrm{C}} \mathrm{C}$ & & C & $\begin{array}{l}+ \\
+\end{array}$ & & $\mathrm{N} 22$ & Pleistocene \\
\hline $600 \mathrm{~B}-1, \mathrm{CC}$ & $\mathrm{C}$ & $\mathbf{P}$ & & + & & $\mathrm{r}$ & & & & & r & & 1 & C & & $\mathrm{F}$ & & & $+r$ & & $\mathrm{~N} 22$ & Pleistocene \\
\hline $\begin{array}{l}600 C-1-1(145-150) \\
600 C-1-2(145-150)\end{array}$ & $\begin{array}{l}\text { A } \\
\text { A }\end{array}$ & $\begin{array}{l}\text { G-M } \\
\text { G-M }\end{array}$ & $\mathrm{r}$ & $\begin{array}{l}\text { C } \\
+\end{array}$ & & & $\begin{array}{l}\mathrm{C} \\
\mathrm{C}\end{array}$ & F & $\mathrm{F}$ & & $\begin{array}{l}c \\
+\end{array}$ & & & & $\mathrm{F}$ & F C F & & & $\mathbf{F}+$ & & $\mathrm{N} 22$ & Pleistocene \\
\hline $\begin{array}{l}600 C-1-4(145-150) \\
600 \mathrm{C}-1-5(145-150) \\
600 \mathrm{C}-1, \mathrm{CC} \\
600 \mathrm{C}-2, \mathrm{CC}\end{array}$ & $\begin{array}{l}\text { A } \\
\text { A } \\
\text { A } \\
\text { C }\end{array}$ & \begin{tabular}{c|}
$\mathrm{M}$ \\
$\mathrm{M}$ \\
$\mathrm{M}-\mathrm{P}$ \\
$\mathrm{M}-\mathrm{P}$
\end{tabular} & & $\begin{array}{l}\mathrm{F} \\
\mathrm{F} \\
\mathrm{C} \\
\mathrm{R}\end{array}$ & $\begin{array}{l}\mathrm{F} \\
+ \\
\mathrm{C} \\
\mathrm{C}\end{array}$ & $\begin{array}{l}r \\
+ \\
C \\
C\end{array}$ & \multicolumn{4}{|c|}{+} & $\begin{array}{l}\text { F } \\
\text { F } \\
\text { C }\end{array}$ & & & $\begin{array}{l}\text { C } \\
\text { C } \\
C \\
C\end{array}$ & $\begin{array}{l}\mathrm{F} \\
\mathrm{F} \\
\mathrm{C} \\
\mathrm{C}\end{array}$ & c & $\begin{array}{l}-\bar{C} \\
\mathrm{~F} \\
\mathrm{~F}\end{array}$ & F & $\begin{array}{l}\mathrm{F} \\
\mathrm{F}\end{array}$ & R F & $\begin{array}{l}\mathrm{N} 20 \\
\mathrm{~N} 19\end{array}$ & $\begin{array}{l}\text { early } \\
\text { Pliocene }\end{array}$ \\
\hline
\end{tabular}

Note: See Table 3 for key. 
Table 6. Site 601 planktonic foraminifer species distribution, abundance, and preservation.

\begin{tabular}{|c|c|c|c|c|c|c|c|c|c|c|c|c|c|c|c|c|c|c|c|c|}
\hline $\begin{array}{c}\text { Sample } \\
\text { (interval in } \mathrm{cm} \text { ) }\end{array}$ & 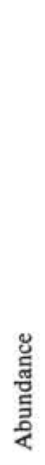 & 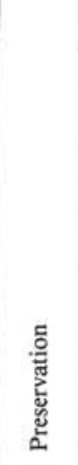 & 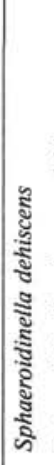 & 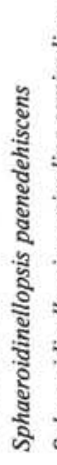 & 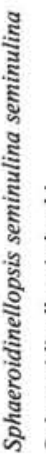 & 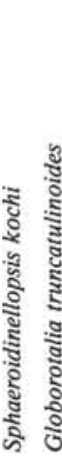 & 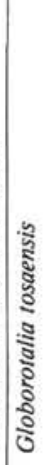 & 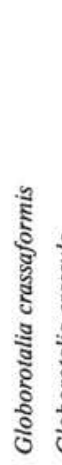 & 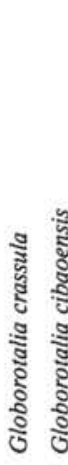 & 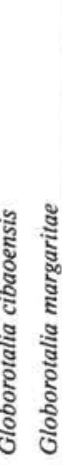 & 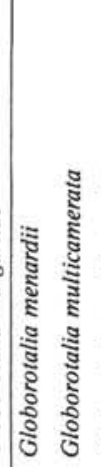 & 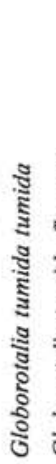 & 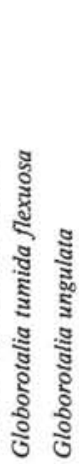 & 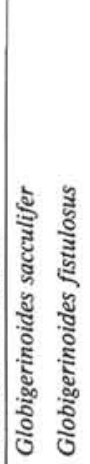 & 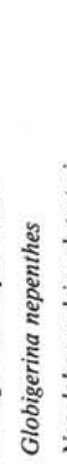 & 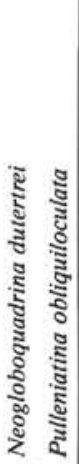 & 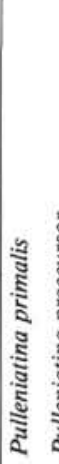 & 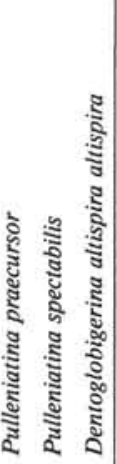 & Zone & $\begin{array}{l}\text { Chrono- } \\
\text { stratigraphy }\end{array}$ \\
\hline $\begin{array}{l}601-1-1(145-150) \\
601-1-2(145-150)\end{array}$ & $\begin{array}{l}\mathrm{A} \\
\mathrm{A}\end{array}$ & $\begin{array}{l}\text { M-G } \\
\text { M-G }\end{array}$ & $\begin{array}{l}\text { C } \\
+\end{array}$ & $\mathrm{r}$ & & $\begin{array}{l}\mathrm{C} \\
\mathrm{F}\end{array}$ & F & + & & & & $\begin{array}{l}\mathrm{C} \\
+\end{array}$ & $\mathrm{r}$ & $\begin{array}{ll}\text { A } & \text { C } \\
& \text { C }\end{array}$ & , & $R^{F}$ & r & r & $\mathrm{N} 22$ & Pleistocene \\
\hline $\begin{array}{l}601-1-4(145-150) \\
601-1-5(145-150)\end{array}$ & $\begin{array}{l}\text { A } \\
\text { A }\end{array}$ & $\begin{array}{l}\mathrm{M} \\
\mathrm{M}\end{array}$ & $\begin{array}{l}+ \\
+\end{array}$ & $\mathrm{r}$ & + & $\begin{array}{l}\mathrm{F} \\
\mathrm{R}\end{array}$ & $\begin{array}{l}\mathrm{C} \\
\mathrm{R}\end{array}$ & $\begin{array}{l}+ \\
+\end{array}$ & F & $\mathrm{r}$ & & $\begin{array}{l}\text { A } \\
\text { C }\end{array}$ & $\begin{array}{lll}\mathrm{F} & \\
\mathrm{F} & \mathrm{R}\end{array}$ & $\begin{array}{l}\mathrm{C} \\
+\end{array}$ & & & $\begin{array}{ll}\mathrm{r} \\
\mathrm{r}\end{array}$ & $\mathbf{R}$ & N21? & $\begin{array}{l}\text { late } \\
\text { Pliocene }\end{array}$ \\
\hline $\begin{array}{l}601-1, C C \\
601-2-2(145-150)\end{array}$ & $\begin{array}{l}\mathrm{A} \\
\mathrm{C}\end{array}$ & $\begin{array}{l}\mathrm{M} \\
\mathrm{M}\end{array}$ & & $\begin{array}{l}\mathrm{F} \\
\mathrm{F}\end{array}$ & + & $\begin{array}{l}r \\
r\end{array}$ & & & $\mathrm{r}$ & $\begin{array}{ll}\mathrm{I} & \mathrm{F} \\
& \mathrm{F}\end{array}$ & & $\begin{array}{l}\text { C } \\
+\end{array}$ & $\begin{array}{l}\mathrm{A} \\
\mathrm{F}\end{array}$ & & $\overline{-}$ & & $\begin{array}{l}F \\
F\end{array}$ & $\begin{array}{r}r \\
+\quad r\end{array}$ & $\mathrm{~N} 20$ & \multirow{2}{*}{$\begin{array}{c}\text { early } \\
\text { Pliocene }\end{array}$} \\
\hline $\begin{array}{l}601-2-4(145-150) \\
601-2, \mathrm{CC} \\
601-3, \mathrm{CC}\end{array}$ & $\begin{array}{l}\mathrm{C} \\
\mathrm{C} \\
\mathrm{C}\end{array}$ & $\begin{array}{l}\mathrm{P} \\
\mathrm{P} \\
\mathrm{P}\end{array}$ & & $\begin{array}{l}\mathrm{F} \\
\mathrm{C} \\
+\end{array}$ & $\begin{array}{l}+ \\
+ \\
+ \\
+\end{array}$ & & & R & $? \mathrm{C}$ & $\begin{array}{ll} & \mathrm{F} \\
\mathrm{C} & \mathrm{F}\end{array}$ & & $\begin{array}{l}\text { C } \\
+\end{array}$ & & & $\begin{array}{l}\mathrm{F} \\
\mathrm{C} \\
\mathrm{C}\end{array}$ & & $\begin{array}{l}\text { C } \\
+\end{array}$ & & N19 & \\
\hline $\begin{array}{l}\text { 601B-1-2 (140-150) } \\
601 \mathrm{~B}-1, \mathrm{CC}\end{array}$ & $\begin{array}{l}\mathrm{F} \\
\mathrm{F}\end{array}$ & $\begin{array}{l}\mathrm{P} \\
\mathrm{P}\end{array}$ & & $\begin{array}{l}\mathrm{F} \\
\mathrm{F}\end{array}$ & $\begin{array}{l}\mathrm{C} \\
\mathrm{C}\end{array}$ & & & & & $\begin{array}{l}\mathrm{R} \\
\mathrm{R}\end{array}$ & R & $\begin{array}{l}\mathrm{C} \\
\mathrm{F}\end{array}$ & & & $\begin{array}{l}\mathrm{C} \\
\mathrm{C}\end{array}$ & & F & $\begin{array}{ll}\mathrm{R} & \mathrm{R} \\
\mathrm{R} & \mathrm{R}\end{array}$ & N19 & $\begin{array}{l}\text { early } \\
\text { Pliocene }\end{array}$ \\
\hline
\end{tabular}

Note: See Table 3 for key.

placed within Core 601-1, Section 3. Zone N20 was determined in the same manner as for Hole $600 \mathrm{C}$, by the presence of Globorotalia margaritae in the absence of Globigerina nepenthes. The oldest samples again were from Zone N19, early Pliocene, as expected from comparison with Hole $600 \mathrm{C}$ (Fig. 2).

A zone of reworked fossils in Section 601-1-6 in the late Pliocene coincides with a sharp decrease in sediment accumulation rates from about $7.5 \mathrm{~m} / \mathrm{m}$.y. to $1 \mathrm{~m} / \mathrm{m}$.y. in Hole $600 \mathrm{C}$ (Fig. 3). The reworking and lower accumulation rate suggest a reduction in deposition or accumulation in the latest Pliocene, which resulted in a possible hiatus at Site 600 . Sites 600 and 601 have been well above the calcite compensation depth throughout their 5-m.y. history, so it is unlikely that dissolution alone can account for the change in sediment accumulation rate.

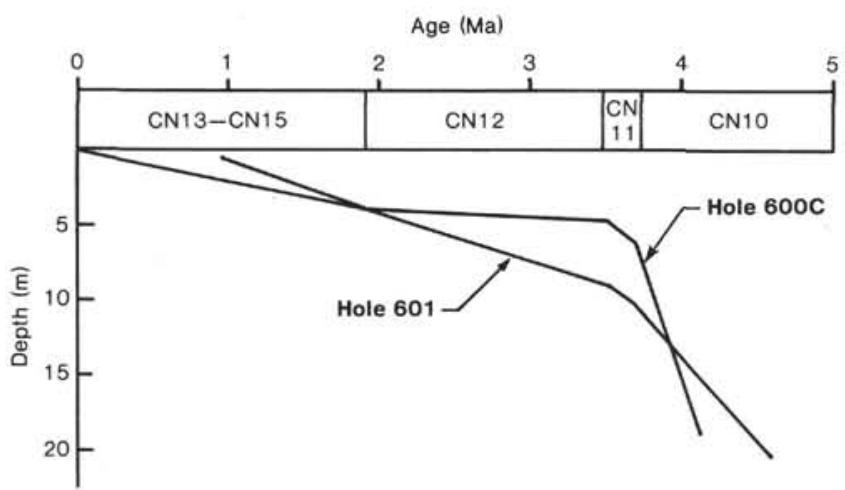

Figure 3. Sediment accumulation curves at Holes $600 \mathrm{C}$ and 601 . Rates were calculated with respect to nannofossil zone boundaries (see Knüttel, this volume).
The reworking of nannofossils noted in this interval suggests a physical rather than chemical explanation for the decreased sediment accumulation rate.

\section{Site 602}

Site 602 (Table 7) was the low-heat-flow site of the set of three on 4.6-Ma crust. Three holes were cored; only Pleistocene material with some reworked Pliocene fossils was recovered. Planktonic foraminifers were abundant and preservation was generally good.

\section{PRESERVATION}

Preservation of planktonic foraminifers varies among the sites and is probably dependent on the depth of the site with respect to the calcite compensation depth (CCD) and/or lysocline at the time of deposition, depth of burial, and sediment accumulation rate (burial rate) (Fig. 4). The exact relationship between the pattern of foraminiferal preservation at each site and the factors that control

Table 7. Site 602 planktonic foraminifer samples.

\begin{tabular}{ll}
\hline $\begin{array}{c}\text { Sample } \\
\text { (interval in cm) }\end{array}$ & Preservation \\
\hline $602 \mathrm{~A}-1, \mathrm{CC}$ & Good \\
$602 \mathrm{~B}-1-2(31-33)$ & Good \\
602B-1-2 (52-54) & Moderate-good \\
602B-1-2 (91-93) & Moderate \\
602B-1-2 (112-114) & Moderate-good \\
602B-1,CC & Good \\
\hline
\end{tabular}

Note: All samples contained abundant foraminifers that were assigned to Pleistocene Zone N22. 


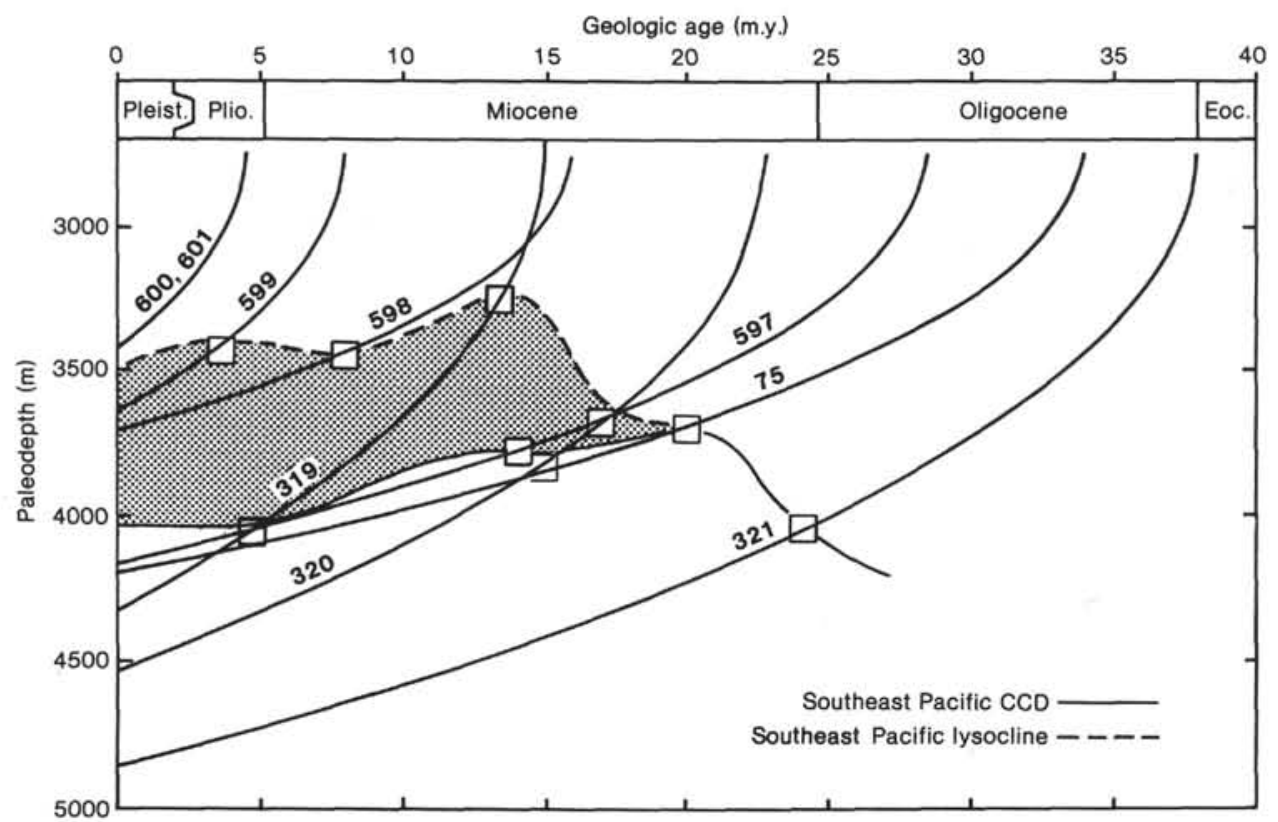

Figure 4. Subsidence curves and the history of the calcite compensation depth for Leg 92 sites (from Rea and Leinen, this volume). Squares are $1 \mathrm{~m} . \mathrm{y} . \times 100 \mathrm{~m}$ and provide an indication of the accuracy of the age/depth data.

preservation are complex and will require further study. However, one observation is worthy of note here. Two of the sites examined, 600 and 601 , have been shallower than both the lysocline CCD throughout their history and should have very well preserved calcareous microfossils. Foraminiferal preservation is good in all except the oldest sediments, which were deposited at the shallowest crustal depth (i.e., far above the CCD). Neither depth relative to the lysocline or CCD, nor the depth of burial (approximately $20 \mathrm{~m}$ of sediment make up the column), appears to be a control on dissolution in those sediments, so some other factor must be involved. These sites are located on relatively young crust which has been hydrothermally active in its past (Lyle et al., this volume). Penetration of hydrothermal solutions into the sediment column may have resulted in increased dissolution of the foraminifers deposited there. More research will be necessary to better determine the effects of hydrothermal solution on the preservation of carbonate in sediments.

\section{SUMMARY}

Leg 92 recovered sediments of uppermost Oligocene through Pleistocene age in a region which heretofore had very poor site coverage. The material recovered was zonable using Blow's tropical zonation scheme. More detailed study of the assemblages found in these sites has potential for use in the determination of the paleoceanographic history of the subtropics of the Southern Hemisphere.

Carbonate dissolution is evident in the cores obtained on Leg 92. It is clear that the history of the lysocline and calcite compensation depth alone does not account for the preservational character of calcareous microfossils at all sites. In most sites the younger samples appear to be the best preserved, while older samples, which presumably were deposited above the lysocline and CCD, seem to be relatively less well preserved. The reason for this phenomenon may be tied to the nature of the crust the oldest sediments were originally deposited on, that is, a crust where active hydrothermal systems existed. The extent of penetration of hydrothermal solutions into these overlying sediments is not well known, nor is the length of time they may have persisted. However, their chemical influence may well have induced or encouraged dissolution of carbonate sediments in contact with the solutions.

\section{ACKNOWLEDGMENTS}

I would like to thank M. Leinen, D. K. Rea, and J. P. Kennett for encouraging me to participate on Leg 92 . I would also like to thank the crew and captain of the Challenger and the other members of the scientific party for a most rewarding experience.

\section{REFERENCES}

Blow, W. H., 1969. Late middle Eocene to Recent planktonic foraminiferal biostratigraphy. In Brönnimann, P., and Renz, H. H. (Eds.), Proc. First Internat. Conf. Planktonic Microfossils (Geneva, 1967): Leiden (E. J. Brill), 199-421.

Srinivasan, M. S., and Kennett, J. P., 1981. Neogene planktonic foraminiferal biostratigraphy and evolution: equatorial to subantarctic, South Pacific. Mar. Micropaleontol., 6:499-533.

Date of Initial Receipt: 6 July 1984

Date of Acceptance: 5 February 1985 